\title{
Adenoid cystic carcinoma of the larynx in a 70-year-old patient: A case report
}

\author{
FILIPPO RICCIARDIELLO ${ }^{1}$, RAFFAELE ADDEO ${ }^{2}$, ANTONELLA MIRIAM DI LULLO ${ }^{3}$, \\ TERESA ABATE ${ }^{1}$, SALVATORE MAZZONE $^{4}$, FLAVIA OLIVA $^{1}$, GIOVANNI MOTTA $^{5}$, \\ MICHELLE CARAGLIA ${ }^{5}$ and MASSIMO MESOLELLA ${ }^{3}$
}

\begin{abstract}
${ }^{1}$ Ear Nose and Throat Unit, ‘Antonio Cardarelli' Hospital, I-80131 Naples; ${ }^{2}$ Oncology Unit, 'San Giovanni di Dio’ Hospital, I-80027 Naples; ${ }^{3}$ Department of Neuroscience, Reproductive and Odontostomatological Science, Ear Nose and Throat Unit, University of Naples 'Federico II', I-80131 Naples; Departments of ${ }^{4}$ Mental and Physical Health and Preventive Medicine, and ${ }^{5}$ Precision Medicine, University of Campania 'L. Vanvitelli', I-80138 Naples, Italy
\end{abstract}

Received April 19, 2015; Accepted July 28, 2016

DOI: $10.3892 / 01.2018 .8976$

\begin{abstract}
Adenoid cystic carcinoma (ACC) is a relatively rare tumor that accounts for $<1 \%$ of all head and neck malignancies. Laryngeal localization of ACC, which is most commonly hypoglottic, is relatively rare, occurring in $0.07-0.25 \%$ of all laryngeal tumors. ACC is characterized as a slow-growing tumor with a high recurrence rate, which often causes dyspnea and hoarseness. ACC exhibits a propensity for perineural invasion and thus, patients may experience pain as a late symptom of the disease. Distant metastasis occurs in $35-50 \%$ of cases and the lungs are the most common site of metastasis. Tumors are usually diagnosed by physical examination with fiberoscopy and computed tomography of the neck and chest, due to the high rate of lung metastases. The standard therapy for ACC is surgery followed by radiotherapy. In this study, a 70-year-old patient presented with laryngeal ACC, who underwent total laryngectomy with bilateral neck dissection and adjuvant radiotherapy, is presented. Follow-up examination performed 2 years after surgery revealed no evidence of locoregional recurrence or distant metastases. Previously published literature regarding ACC of the larynx was also reviewed.
\end{abstract}

\section{Introduction}

Adenoid cystic carcinoma (ACC) is a malignant neoplasm of the epithelium, which occurs in the major and minor salivary glands (1). In 1859, Billroth used the term 'cylindroma' to describe the standard histology of salivary gland tumors, however, this was replaced by the term 'ACC' in $1953(2,3)$.

Correspondence to: Dr Raffaele Addeo, Oncology Unit, 'San Giovanni di Dio' Hospital, Via Pirozzi 62, I-80027 Naples, Italy E-mail: lelloaddeo@alice.it

Key words: adenoid cystic carcinoma, laryngectomy, radiotherapy, epidermal growth factor receptor
$\mathrm{ACC}$ is a relatively rare tumor, accounting for $<1 \%$ of all head and neck malignancies and $7.5-10 \%$ of all salivary gland neoplasms (3-6).

Laryngeal localization of ACC, which is most frequently hypoglottic, is relatively rare, occurring in $0.07-0.25 \%$ of all laryngeal tumors $(5,7,8)$. ACC tumors arise from submucosal minor salivary glands, in which laryngotracheal mucosa is sparse $(5,9)$. The majority of the minor salivary glands are located in the subglottis $(60 \%)$, however, they are also identified in the supraglottis, false vocal cords, aryepiglottic folds and caudal aspect of the epiglottis $(5,7,10)$. Tumors of the minor salivary glands are usually malignant and ACC presents the most common tumor type $(5,7)$. These tumors most frequently occur in the oral cavity, particularly in the hard palate, however, tumors are less common in the nasal cavity, paranasal sinuses, pharynx and larynx $(5,11)$, due to the distribution of minor salivary glands in these regions. ACC most commonly occurs in patients aged between 50 and 60 years old with no gender predilection (11). Laryngeal ACC is characterized as a slowly-growing tumor with symptoms that are dependent on the location of the tumor. For example, certain patients present with dyspnea, while patients with lesions that involve the true vocal cords present with hoarseness and dysphagia that is associated with ear pain (12). Distant metastasis is observed in $35-50 \%$ of ACC cases and most commonly occurs in the lungs (2). Diagnostic modalities include physical examination with fiberoscopy and computed tomography of the neck and chest in order to identify lung metastases, which are extremely common (13). At present, surgery followed by radiotherapy is the standard treatment for ACC (10). Approximately 50\% of ACC patients experience recurrence within 5 years of diagnosis, however, ACC exhibits a fairly good prognosis, with a 5-year overall survival rate of $70 \%$ (14).

To the best of our knowledge, in the last 15 years a total of 81 cases of ACC of the larynx have been reported in the literature (Table I). In this study, a case of laryngeal ACC in a 70-year-old man, which was a candidate for total laryngectomy with bilateral neck dissection and adjuvant radiotherapy, is presented. 


\section{Case report}

In May 2012, a 70-year-old man presented to the Department of Otolaryngology-Head and Neck Surgery at 'Federico II' University (Naples, Italy) with ear pain, dysphonia, a 1-year history of dysphagia and a 1-month history of dyspnea. The patient was a former smoker (80 cigarettes/day for 50 years) and had previously been diagnosed with diabetes mellitus and chronic renal failure, which had been managed with dialysis for 10 years.

Laryngoscopy revealed a bulging mass in the left true vocal cord and left ventricle, which extended to the subglottic area with lack of mobility of the left larynx (Fig. 1). In the neck, left lymph nodes were palpable (level III). Total body positron emission tomography-computed tomography (PET-CT) with contrast medium revealed hyperaccumulation of tracer in the left laryngeal region (standardized uptake volume, 7.9) (Fig. 2). Magnetic resonance imaging (MRI) of the neck with contrast medium revealed asymmetric reduction of the laryngeal glottic plane and the presence of a solid, inhomogeneous lesion with evidence of increased perfusion predominantly in the left true vocal cord $(28 \times 37 \mathrm{~mm})$.

This lesion laterally destroyed the paraglottic space, upward interesting the ipsilateral false vocal cord and anteriorly reaching the anterior commissure; posteriorly and inferiorly it was associated with mixed structural alteration mainly thickening of the left arytenoid cartilage, especially in his vocal process, and the posterosuperior and lateral portion of the cricoid cartilage, which exhibited moderate and uniform contrast enhancement suggesting infiltrative growth into nearby structures (Fig. 3). In addition, neck MRI revealed an enlarged left cervical lymph node, measuring $1.8 \mathrm{~cm}$ in diameter. Clinical staging was T3N1M0 (stage III, according to the Union for International Cancer Control/American Joint Committee on Cancer staging system) (38).

Biopsy of the tumor mass by direct microlaryngoscopy in suspension revealed a cellular neoplasm with prominent cribriform architecture, which was composed of small, bland hyperchromatic cells with a high nuclear-to-cytoplasmic ratio. The neoplastic cells surrounding the pseudoglandular spaces were filled with basement membrane-like material and mucin (Fig. 4).

Subsequently, the patient underwent total laryngectomy with bilateral selective neck dissection (levels II-IV, left side; levels II-III, right side).

Tissue sections $(3-5 \mu \mathrm{m})$ from each specimen were mounted on glass slides and dried overnight at $37^{\circ} \mathrm{C}$. All sections were deparaffinized in xylene, rehydrated through a graded alcohol series and washed in phosphate-buffered saline. Tissue sections were processed using the standard streptavidin-biotin-immunoperoxidase method (Dako LSAB2 Universal Kit; Dako, Carpinteria, CA, USA). Rabbit polyclonal anti-human c-kit antibody (CD117; catalog no. 34-8800; Dako) at 1:50 dilution was used according to the manufacturer's protocols. Hematoxylin and eosin (Sigma-Aldrich; Merck KGaA, Damrstadt, Germany) stain was used as the final chromogen. Histological examination identified the presence of ACC, which exhibited focal solid areas and infiltration of the cartilage and fibroadipose perilaryngeal tissues with perineural invasion. All dissected neck lymph nodes were

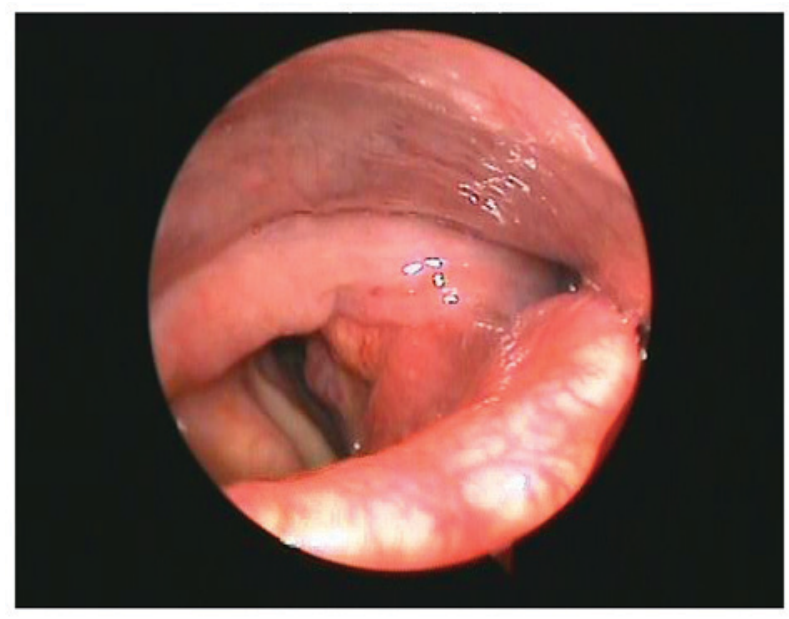

Figure 1. Laryngoscopy revealed a bulging mass in the left true vocal cord and left ventricle extending to the subglottic area with fixity of the left larynx.

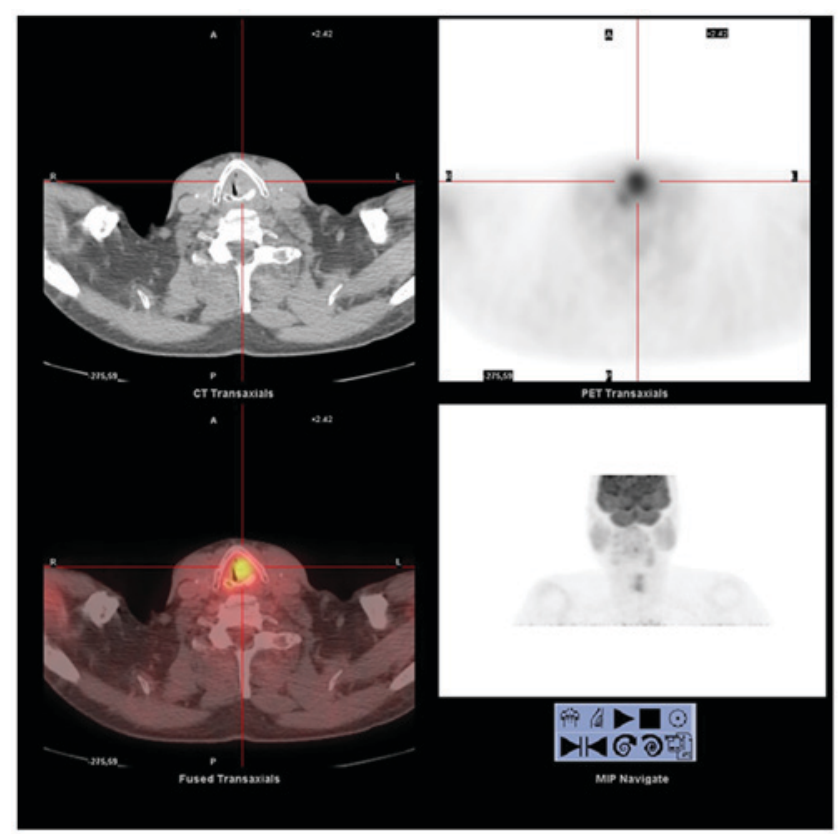

Figure 2. Total body positron emission tomography-computed tomography with contrast medium revealed hyperaccumulation of tracer in the left laryngeal region (standardized uptake volume, 7.9).

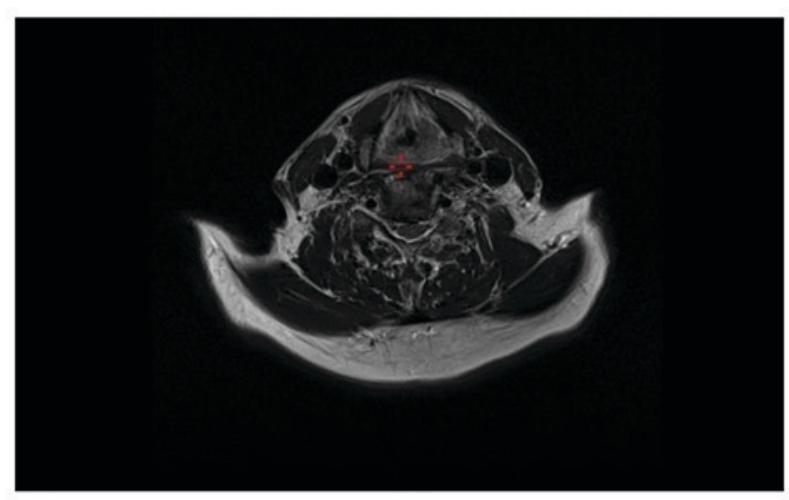

Figure 3. Neck magnetic resonance imaging with contrast medium revealed asymmetric reduction of the laryngeal glottic plane due to the presence of a solid, inhomogeneous lesion. Increased perfusion was observed predominantly in the left true vocal cord $(28 \times 37 \mathrm{~mm})$. 
Table I. Previous case reports of adenoid cystic carcinoma arising in the larynx reported in the English language literature over the last 15 years.

\begin{tabular}{|c|c|c|c|c|c|}
\hline First author/s, year & Case(s), n & Primary tumor localization & $\begin{array}{l}\text { Recurrence sites } \\
\text { (local-regional/ } \\
\text { distant metastases) }\end{array}$ & Survival & Ref. \\
\hline Javadi et al, 2002 & 1 & Subglottis & ND & ND & (1) \\
\hline Saraydaroglu et al, 2011 & 1 & Supraglottis-glottis & ND & ND & (5) \\
\hline Ganly et al, 2006 & 12 & Larynx & ND & ND & (7) \\
\hline Lee et $a l, 2003$ & 1 & Larynx & ND & ND & $(15)$ \\
\hline Del Negro et al, 2007 & 1 & Subglottis & ND & ND & (16) \\
\hline Amit et al, 2014 & 6 & Larynx & ND & $\begin{array}{l}\text { NED - Follow-up } \\
\text { period 3-288 months } \\
\text { (median, } 64 \text { months) }\end{array}$ & $(17)$ \\
\hline Qian et al, 2014 & 1 & Supraglottis & $\begin{array}{l}\text { Regional recurrence } \\
\text { [supraglottis, glottis } \\
\text { and subglottis }(1 \mathrm{~cm})]\end{array}$ & $\begin{array}{l}\text { NED-42 months } \\
\text { follow-up }\end{array}$ & $(18)$ \\
\hline \multirow[t]{2}{*}{ Misiukiewicz et al, 2013} & 1 & Transglottic & $\begin{array}{l}\text { Distant metastases } \\
\text { (pulmonary metastases at } \\
54 \text { months) }\end{array}$ & $\begin{array}{l}\text { Alive, } 112 \text { months } \\
\text { follow-up }\end{array}$ & (19) \\
\hline & 1 & Glottis & None & $\begin{array}{l}\text { NED - } 60 \text { months } \\
\text { follow-up }\end{array}$ & \\
\hline Testa et al, 2013 & 1 & Glottis-subglottis & ND & $\begin{array}{l}\text { NED - } 36 \text { months } \\
\text { follow-up }\end{array}$ & $(20)$ \\
\hline Murray et al, 2010 & 1 & Larynx & $\begin{array}{l}\text { Lung metastasis and } \\
\text { splenic lesion }\end{array}$ & ND & $(21)$ \\
\hline $\begin{array}{l}\text { Zvrko and Golubović, } \\
2009\end{array}$ & 1 & Subglottis & ND & $\begin{array}{l}\text { NED - } 6 \text { months } \\
\text { follow-up }\end{array}$ & $(22)$ \\
\hline Wang et al, 2009 & 1 & Subglottis & ND & $\begin{array}{l}\text { NED - } 6 \text { months } \\
\text { follow-up }\end{array}$ & (23) \\
\hline Zeng et al, 2009 & 10 & Supraglottis/Subglottis & ND & ND & (24) \\
\hline Maukarbel et al, 2008 & 15 & $\begin{array}{c}\text { Supraglottis }(2 ; 13.3 \%), \\
\text { glottis }(1 ; 6.6 \%), \\
\text { subglottis }(9 ; 60 \%) \text { and } \\
\text { transglottis }(3 ; 20 \%)\end{array}$ & $\begin{array}{l}\text { Distant metastases ( } 7), \\
\text { local/distant (2), } \\
\text { local residual (1), } \\
\text { none (3) and } \\
\text { regional (2) }\end{array}$ & $\begin{array}{l}6 \text { patients alive } \\
\text { (1 NED), } 9 \text { patients } \\
\text { succumbed ( } 7 \text { from } \\
\text { their disease. } 6.9 \text { years } \\
\text { follow-up (range, } \\
1.3-22.3 \text { years) }\end{array}$ & $(25)$ \\
\hline Aydin et al, 2008 & 1 & Subglottis & None & NED - 6 years & (26) \\
\hline Messaoudi et al, 2007 & 1 & Subglottis & None & NED - 6 months & (27) \\
\hline Khan et al, 2006 & 1 & Subglottis & ND & ND & $(28)$ \\
\hline Pino Rivero et al, 2006 & 1 & Larynx & Pulmonary metastases & NED - 1 year & (29) \\
\hline Natarajan et al, 2004 & 1 & Larynx & ND & ND & $(30)$ \\
\hline Adachi et al, 2003 & 1 & Larynx & $\begin{array}{l}\text { Choroidal/optic disc } \\
\text { metastasis }\end{array}$ & ND & $(31)$ \\
\hline Dexemple et al, 2003 & 2 & Larynx & ND & ND & $(32)$ \\
\hline Mahlstedt et al, 2002 & 6 & Larynx & ND & ND & (33) \\
\hline Issing et al, 2002 & 3 & Larynx & ND & ND & (34) \\
\hline Altaf, 2001 & 1 & Larynx & ND & ND & $(35)$ \\
\hline Szmeja et al, 2001 & 1 & Larynx & ND & ND & (36) \\
\hline Lucioni et al, 2015 & 8 & $\begin{array}{l}\text { Supraglottis (2), } \\
\text { transglottis (1) and } \\
\quad \text { subglottis (5) }\end{array}$ & Regional metastases (2) & $\begin{array}{l}\text { NED - } 41 \text { months } \\
\text { median follow-up } \\
\text { (range, 14-301 } \\
\text { months) }\end{array}$ & $(37)$ \\
\hline
\end{tabular}

NED, no evidence of disease; ND, not determined. 


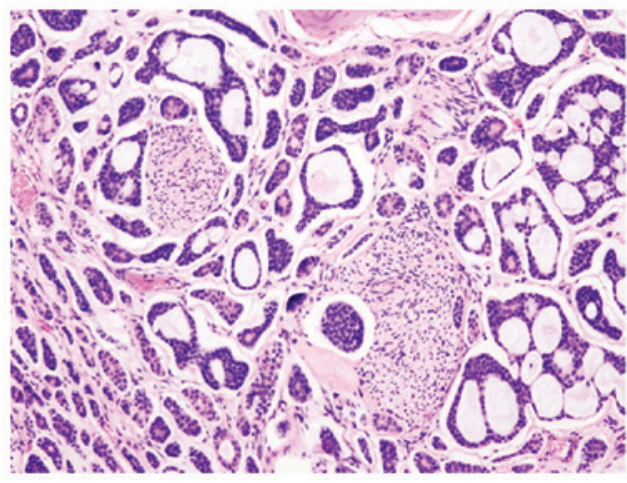

Figure 4. Hematoxylin/eosin staining of an adenoid cystic carcinoma. Magnification, $\mathrm{x} 10$.

free of metastases. Immunohistochemical analysis of ACC cells revealed positivity for the c-kit protein. Subsequently, the tumor was pathologically staged as ACC T3NOM0 (stage III).

The patient was administered adjuvant radiotherapy (66 Gy) for 6 weeks according to recent guidelines (39). Follow-up examinations were performed every 6 months and follow-up 2 years after surgery revealed no evidence of locoregional recurrence or distant metastases.

\section{Discussion}

ACC of the larynx most commonly occurs in patients aged between 40 and 60 years-old $(5,11,15)$. However, in the present case, ACC of the larynx was diagnosed in a 70-year-old patient. In the last 15 years, a total of 81 laryngeal ACCs have been reported and well-documented in the English literature (Table I). ACC is the predominant histological type among malignancies of the minor salivary glands, with a frequency of $10-20 \%$, representing only $2-4 \%$ of all head and neck malignancies. ACC of the larynx is incredibly rare (0.07-0.25\% of all laryngeal tumours, $1 \%$ of all ACC) as there are few salivary glands in the mucosa of laryngeal-tracheal tract (5). These tumors are predominantly subglottic (64\%), such as in the present case. Moreover, their prevalence is $25 \%$ for the supra-glottic region, $5 \%$ for the glottic region and $6 \%$ for the trans-glottic area. This pattern of distribution in the anatomical laryngeal subsites is due to their origin from submucosal glands, which are more frequently found in the subglottic region of the larynx $(1,5,7,15,16-37)$. These tumors grow slowly with perineural diffusion (37). So the evolution prognosis of this disease is caused by lung, bone and brain metastases or by local recurrence $(20,37)$.

ACC of the larynx develops in a similar manner to ACC of other head and neck sites. It is considered a slowly growing but highly invasive cancer with a high recurrence rate.

In the laryngeal region, symptoms depend on the tumor location. Patients with subglottic cancer show dyspnea, whereas common symptoms of glottis implications are dyspnea and a hoarse voice. Subglottic tumors are rare and associated with stridor and airway obstruction (12). In the present clinical case, an initial glottic and supraglottic lesion infiltrating the left true vocal cord and left ventricle caused hoarseness (due to vocal cord compromise) and dysphagia associated with ear pain for 1 year (10), and subsequently, the major extension of the lesion to the subglottic region resulted in dyspnea (due to airway obstruction) over the last month.

In the present case, physical and radiological examinations identified an enlarged left cervical lymph node, $1.8 \mathrm{~cm}$ in diameter with no evidence of distant metastasis. Previously it has been reported that nodal metastasis is a common cause of treatment failure in ACC patients (16), however, metastasis to the cervical lymph nodes is rare in ACC, occurring in $10-20 \%$ of patients with head and neck ACC (38). Notably, the metastasis rates of ACC located in the base of the tongue (19.2\%), mobile tongue (17.6\%) and mouth floor (15.3\%) are higher than that of ACC of the larynx (15). In addition, clinical investigations have shown that the incidence of ACC with distant metastasis ranges from 35 to $50 \%$, and leads to 5-year survival rates ranging from $12-17 \%$ following surgery (12). The lungs are the most common site of distant metastasis from ACC (15).

We recommend that neck dissection is performed in all ACC patients with pre-operative evidence of nodal metastases, as indicated by physical examination and imaging studies including CT, MRI and/or PET-CT, since occult cervical metastases of head and neck ACC occurs in 10-20\% of cases (38).

The prognostic factors of ACC are dependent on tumor site, tumor stage and microscopic tumor pattern. Other prognostic factors are an age $>60$ years, a solid histological subtype, an advanced clinical stage and the presence of perineural invasion $(5,40)$.

In the patient of the present case, the ACC tumor was mainly localized to the glottis and supraglottic area, causing hoarseness and dysphagia; however, major extension of the lesion to the subglottic region resulted in dyspnea leading to a late diagnosis. In the larynx, tumor occurrence in the minor salivary glands is rare, accounting for $<1 \%$ laryngeal tumors (5). The tumors arise from submucosal minor salivary glands, which exhibit a distinct anatomical distribution in the larynx. The majority of minor salivary glands are concentrated in the subglottis, however, they may also be identified in the supraglottis in the false vocal cords, aryepiglottic folds and caudal aspect of the epiglottis (5). The anatomical site in which laryngeal submucosal minor salivary glands are located explains the evolution of the symptoms in the present clinical case.

The patient in the present case was initially diagnosed with clinical stage III (cT3N1M0) disease, as tumor extension to the vocal cords with emilaryngeal lack of mobility (T3) and a metastatic omolateral lymph node (N1) were observed with no evidence of distant metastases (M0) (5). Tumor staging was postoperatively confirmed as T3NOM0 since all dissected neck lymph nodes were free of metastases.

According to the World Health Organization Classification of Tumors (41), ACC may be divided into three microscopic grades: Tubular (well-differentiated/grade I), which exhibits the best prognosis; cribriform (moderately-differentiated/grade II), which is the most common; and solid (poorly-differentiated/grade III), which is the least common with the worst prognosis $(5,16,17)$. ACC tumors often exhibit a mixture of the three histological growth patterns and thus, tumors are classified according to the predominant pattern (42). The tumor in the present case exhibited a 
classic cribriform pattern and thus was defined as low-grade (grade II).

Generally, neoplastic ACC cells exhibit myoepithelial and ductal differentiation, with positivity for p63, S100 protein, smooth muscle actin and cytokeratins (43). Typically, the most peripheral cells of the tumor nests and glands are arranged in a cribriform pattern and exhibit myoepithelial differentiation that is accompanied by the abundant production of extracellular matrix and basement membrane components, such as laminin (43). Loss of laminin or reduced expression may occur during transformation to a more aggressive malignancy $(3,44)$. In the present case, immunochemistry revealed positivity for c-kit protein, a class III transmembrane receptor tyrosine kinase. C-kit is a proto-oncogene encoded by a gene located on the human chromosome segment $4 \mathrm{q} 11$, which leads to activation of specific intracellular signal transduction cascades that contribute to the cellular growth and differentiation that subsequently confers a worse prognosis (11). Thus, further investigation is required to characterize c-kit functional pathways in salivary gland tumors and to evaluate potential therapeutic effects of small molecule inhibitors of c-kit, such as imatinib mesylate (42). In $\mathrm{ACC}, \mathrm{c}-\mathrm{kit}$ expression is limited to the inner epithelial cells, whereas epidermal growth factor receptor (EGFR) is typically expressed in myoepithelial cells. EGFR, which facilitates carcinogenesis in humans via the blockade of apoptosis and promotion of angiogenesis, may be modified by anti-EGFR agents, including cetuximab and erlotinib. In addition, recent studies have reported that cytogenetically, ACC is characterized by the tumor-type specific translocation, $\mathrm{t}(6 ; 9)$ (q22-23;p23-24), which has been identified as the sole anomaly in certain cases. This traslocation results in the fusion of the MYB proto-oncogene and the transcription factor gene nuclear factor I-B (NFIB), leading to the formation of the MYB-NFIB fusion oncogene, which is highly overexpressed in ACC; thus, it may be considered a useful biomarker for the disease $(3,11)$.

At present, surgery followed by radiotherapy is the standard treatment for ACC due to the risk of perineural and hematogenous spread. According to the literature, surgical excision of the lesion is recommended due to the relative radioresistance of these tumors. Surgical excision should be performed with bilateral selective neck dissection in cases where frozen sections reveal negative lymph nodes (no tumoral infiltration) (pN0) and with radical neck dissection in cases whereby frozen sections reveal positive lymph nodes (pN+) (39).

The patient in the present case underwent total laryngectomy associated with bilateral selective neck dissection (levels II-IV, left side; levels II-III, right side). Furthermore, frozen biopsy sections revealed that negative lymph nodes were negative for metastasis (pN0) and thus adjuvant radiotherapy (66 Gy) was administered according to recent guidelines (39).

Postoperative radiation is recommended in certain cases, as radiotherapy has been demonstrated to result in tumor regression and symptomatic relief (16). However, the use of chemotherapy for ACC remains controversial. Certain studies have demonstrated positive patient responses to chemotherapy and thus, it is recommended as palliative therapy in advanced cases $(5,17)$.
However, currently, the identification of molecular abnormalities underlying ACC, such as those of c-kit and EGFR, is paramount for the development of specific targeted therapies.

Previous case reports of ACC in the larynx during the last 14 years are listed in Table I (1,5,7,15-37).

After 2 years of post-operative follow-up, performed every 6 months, the patient in the current study remained free of locoregional recurrence and/or distant metastases.

In conclusion, $\mathrm{ACC}$ is a relatively rare tumor comprising $<1 \%$ of all malignancies of the head and neck area. ACC of the larynx occurs more commonly in middle-aged or older patients, evolving slowly and with patients mainly developing dyspnea. In addition, it is considered a highly invasive cancer with a high recurrence rate and an incidence of distant metastasis ranging from 35 to $50 \%$, resulting in a low longterm survival rate (12). It has been well-documented that the most common site of distant metastasis from ACC is the lung. In localized ACC, the gold-standard therapy is surgery followed by adjuvant radiotherapy. Novel therapeutic frontiers will focus on the identification of molecular abnormalities underlying ACC, such as c-kit and EGFR, to develop specific targeted therapies.

\section{References}

1. Javadi M, Bafrouee FM, Mohseni M and Asghari A: Laryngeal adenoid cystic carcinoma in a child: A case report. Ear Nose Throat J 81: 34-35, 2002.

2. Soares EC, Carreiro Filho FP, Costa FW, Vieira AC and Alves AP: Adenoid cystic carcinoma of the tongue: Case report and literature review. Med Oral Pathol Oral Cir Bucal 13: E475-E478, 2008.

3. Anupriya S, Mahesh P, Sharada P, Swaminathan U, Nagamalini B and Hosthor SS: Immunohistochemical analysis of laminin expression in adenoid cystic carcinoma. J Oral Maxillofac Pathol 18 (Suppl 1): S26-S31, 2014.

4. Sadeghi A, Tran LM, Mark R, Sidrys J and Parker RG: Minor salivary gland tumors of the head and neck: Treatment strategies and prognosis. Am J Clin Oncol 16: 3-8, 1993.

5. Saraydaroglu O, Coskun $\mathrm{H}$ and Kasap M: Unique presentation of adenoid cystic carcinoma in postcricoid region: A case report and review of the literature. Head Neck Pathol 5: 413-415, 2011.

6. Barrett AW and Speight PM: Perineural invasion in adenoid cystic carcinoma of the salivary glands: A valid prognostic indicator? Oral Oncol 45: 936-940, 2009.

7. Ganly I, Patel SG, Coleman M, Ghossein R, Carlson D and Shah JP: Malignant minor salivary gland tumors of the larynx. Arch Otolaryngol Head Neck Surg 132: 767-770, 2006.

8. Serafini I, Lucioni M, Bittesini L, Dei Tos AP and Della Libera D: Treatment of laryngeal adenoid cystic carcinoma. Acta Otorhinolaryngol Ital 11: 13-24, 1991 (In Italian).

9. Bak-Pedersen K and Nielsen KO: Subepithelial mucous glands in the adult human larynx. Studies on number, distribution and density. Acta Otolaryngol 102: 341-352, 1986.

10. Karasmanis I, Goudakos JK, Vital I, Zarampoukas T, Vital V and Markou K: Hybrid carcinoma of the larynx: A case report (adenoid cystic and adenocarcinoma) and review of the literature. Case Rep Otolaryngol 2013: 385405, 2013.

11. Brill LB II, Kanner WA, Fehr A, Andrén Y, Moskaluk CA, Löning T, Stenman G and Frierson HF Jr: Analysis of MYB expression and MYB-NFIB gene fusions in adenoid cystic carcinoma and other salivary neoplasms. Mod Pathol 24: 1169-1176, 2011.

12. Li G, Chen J, Zhang S, Lin J, Kong F, Cai F and Yang S: Adenoid cystic carcinoma of the larynx: A report of two cases. Oncol Lett 10: 2303-2306, 2015.

13. Joshi VM, Wadhwa V and Mukherji SK: Imaging in laryngeal cancers. Indian J Radiol Imaging 22: 209-226, 2012.

14. Lin YC, Chen KC, Lin CH, Kuo KT, Ko JY and Hong RL: Clinicopathological features of salivary and non-salivary adenoid cystic carcinomas. Int J Oral Maxillofac Surg 41: 354-360, 2012. 
15. Lee LA, Fang TJ, Li HY and Lee KF: Adenoid cystic carcinoma of the supraglottis mimicking a laryngeal cyst. Otolaryngol Head Neck Surg 129: 157-158, 2003.

16. Del Negro A, Ichihara E, Tincani AJ, Altemani A and Martins AS: Laryngeal adenoid cystic carcinoma: Case report. Sao Paulo Med J 125: 295-296, 2007.

17. Amit M, Na'ara S, Sharma K, Ramer N, Ramer I, Agbetoba A, Glick J, Yang X,Lei D, Bjoerndal K, et al: Elective neck dissection in patients with head and neck adenoid cystic carcinoma: An international collaborative study. Ann Surg Oncol 22: 1353-1359, 2015.

18. Qian X, Zhou H, Gu Y, Zhang Y and Gao X: Supraglottic adenoid cystic carcinoma mimicking laryngeal amyloidosis: A case report. Oncol Lett 7: 2154-2156, 2014.

19. Misiukiewicz KJ, Camille N, Tishler R, Haddad R, Limaye S and Posner M: Organ preservation for adenoid cystic carcinoma of the larynx. Oncologist 18: 579-583, 2013.

20. Testa D, Guerra G, Conzo G, Nunziata M, D'Errico G, Siano M, Ilardi G, Vitale M, Riccitiello F and Motta G: Glottic-Subglottic adenoid cystic carcinoma. A case report and review of the literature. BMC Surgery 13 (Suppl 2): S48, 2013.

21. Murray BW, Lyons LC, Mancino AT and Huerta S: A report of laryngeal adenocystic carcinoma metastatic to the spleen and the role of splenectomy in the management of metastatic disease: A case report. J Med Case Rep 4: 207, 2010.

22. Zvrko E and Golubović M: Laryngeal adenoid cystic carcinoma. Acta Otorhinolaryngol Ital 29: 279-282, 2009.

23. Wang HL, Xu L and Li FJ: Subglottic adenoid cystic carcinoma mistaken for asthma. J Zhejiang Univ Sci B 10: 707-710, 2009.

24. Zeng Q, Tang PZ, Xu ZG, Qi YF, Wu XX and Liu WS: Malignant minor salivary gland tumors of the larynx. Zhongua Er Bi Yan Hou Tou Jing Wai Ke Za Zhi 44: 40-43, 2009 (In Chinese).

25. Maukarbel RV, Goldstein DP, O'Sullivan B, Gullane PJ, Brown DH, Wang L and Irish JC: Adenoid cystic carcinoma of the larynx: A 40-year experience. Head Neck 30: 919-924, 2008

26. Aydin $\mathrm{O}$, Ustünda $\breve{g} \mathrm{E}$, Işeri $\mathrm{M}$ and Erçin $\mathrm{C}$ : Laringeal adenoid cystic carcinoma in an adolescent. Kulak Burun Bogaz Ihtis Derg 18: 319-322, 2008

27. Messaouidi C, Larouk R, Baili S, Noui B, Benchaoui M, Benkadri $\mathrm{H}$ and Belbekri F: Adenoid cystic carcinoma of the larynx. A case report and review of the literature. Rev Laryngol Otol Rhinol (Bord) 128: 97-100, 2007 (In French).

28. Khan AR, Jan A, Nawaz G and Zaman N: Adenoid cystic carcinoma of larynx. J Coll Physicians Surg Pak 16: 669-670, 2006.

29. Pino Rivero V, Pantoja Hernández CG, González Palomino A Trinidad Ramos G, Pardo Romero G, Marcos García M, Pereda Tamayo JM and Blasco Huelva A: Adenoid cystic carcinoma of the larynx-hypopharynx. A case report and review of the literature. An Otorrinolaringol Ibero Am 33: 339-345, 2006 (In Spanish).

30. Natarajan S, Greaves TS, Raza AS and Cobb CJ: Fine-needle aspiration of an adenoid cystic carcinoma of the larynx mimicking a thyroid mass. Diagn Cytopathol 30: 115-118, 2004.
31. Adachi N, Tsuyama Y, Mizota A, Fujimoto N, Suehiro S and Adachi-Usami E: Optic disc metastasis presenting as an initial sign of recurrence of adenoid cystic carcinoma of the larynx. Eye (Lond) 17: 270-272, 2003.

32. Dexemple P, Huth J, Rebufy M and Chabrol A: Cystic adenoid carcinoma of the larynx: Two cases. Ann Otolaryngol Chir Cervicofac 120: 244-248, 2003 (In French).

33. Mahlstedt K, Ussmüller J and Donath K: Malignant sialogenic tumours of the larynx. J Laryngol Otol 116: 119-122, 2002.

34. Issing PR, Hemmanouil I, Wilkens L, Karstens H and Lenarz T: Long term results in adenoidcystic carcinoma. Laryngorhinootologie 81: 98-105, 2002 (In German).

35. Altaf FJ: Histopathology of adenoid cystic carcinoma of the larynx and adenocarcinoma hybrid. Saudi Med J 22: 920-923, 2001.

36. Szmeja Z, Wierzbicka M, Szyfter W and Woźniak A: A rare case of adenoid cystic carcinoma of the larynx. Otolaryngol Pol 55: 203-206, 2001 (In Polish).

37. Lucioni M, Bertolin A, Lionello M and Rizzotto G: Terapia chirurgica nelle localizzazioni primitive laringee e della giunzione laringotracheale. In: Il carcinoma adenoido-cistico nel distretto cervico-facciale. Quaderni monografici di aggiornamento A.O.O.I. - 2015, pp195-206 (In Italian).

38. Edge SB, Byrd DR, Compton CC, Fritz AG, Greene FL and Trotti A III (eds): Larynx AJCC Cancer Staging Manual. 7th edition. Springer, New York, pp57-62,2010.

39. Pinto C, Maiello E, Moschetti I,Cinquini M, Torri V, Pappagallo G and Gori S: Head Neck Tumors Guidelines. In: AIOM Guidelines. Italian Association of Medical Oncology-AIOM, 2015. www.aiom.it. Accessed, 5 Oct 2015.

40. Norberg-Spaak L, Dardick I, Ledin T. Adenoid cystic carcinoma: use of cell proliferation, BCL-2 expression, histologic grade, and clinical stage as predictors of clinical outcome. Head Neck 22: 489-97, 2000

41. Barnes L, Eveson JW, Reichart P and Sidransky D (eds): World Health Organization Classification of Tumours. Pathology and Genetics of Head and Neck Tumours. IARC Press, Lyon, 2005.

42. Kokemueller H, Eckardt A, Brachvogel P and Hausamen JE: Adenoid cystic carcinoma of the head and neck - a 20 years experience. Int J Oral Maxillofac Surg 33: 25-31, 2004.

43. Salehinejad J, Mohtasham N, Bagherpour A, Abbaszadeh-Bidokhty $\mathrm{H}$ and Ghazi A: Evaluation of c-kit protein (CD117) expression in common salivary gland neoplasms. J Oral Maxillofac Pathol 18: 177-182, 2014.

44. Mesolella M, Iengo M, Testa D, Di Lullo AM, Salzano G and Salzano FA: Mucoepidermoid carcinoma of the base of tongue. Acta Otorhinolaryngol Ital 35: 58-61, 2015.

This work is licensed under a Creative Commons Attribution-NonCommercial-NoDerivatives 4.0 International (CC BY-NC-ND 4.0) License. 